\title{
Henry Kissinger: Negotiating Black Majority Rule in Southern Africa
}

\section{Citation}

Sebenius, James K., R. Nicholas Burns, Robert H. Mnookin, and L. Alexander Green. "Henry Kissinger: Negotiating Black Majority Rule in Southern Africa." Harvard Business School Working Paper, No. 17-051, December 2016

\section{Permanent link}

http://nrs.harvard.edu/urn-3:HUL.InstRepos:30011597

\section{Terms of Use}

This article was downloaded from Harvard University's DASH repository, and is made available under the terms and conditions applicable to Open Access Policy Articles, as set forth at http:// nrs.harvard.edu/urn-3:HUL.InstRepos:dash.current.terms-of-use\#OAP

\section{Share Your Story}

The Harvard community has made this article openly available.

Please share how this access benefits you. Submit a story.

Accessibility 


\section{Henry Kissinger: Negotiating Black Majority Rule in Southern Africa}

James K. Sebenius

Robert H. Mnookin
R. Nicholas Burns

L. Alexander Green

Working Paper 17-051 


\section{Henry Kissinger: Negotiating Black Majority Rule in Southern Africa}

James K. Sebenius

Harvard Business School

Robert H. Mnookin

Harvard Law School
R. Nicholas Burns

Harvard Kennedy School

L. Alexander Green

Harvard Business School

Working Paper 17-051 


\title{
Henry Kissinger: Negotiating Black Majority Rule in Southern Africa
}

\author{
by James K. Sebenius, R. Nicholas Burns, Robert H. Mnookin, and L. Alexander Green* \\ December 9, 2016 v1.2
}

\begin{abstract}
In 1976, United States Secretary of State Henry A. Kissinger conducted a series of intricate, multiparty negotiations in Southern Africa to persuade white Rhodesian leader Ian Smith to accede to black majority rule. Conducted near the end of President Gerald Ford's term in office, against substantial U.S. domestic opposition, Kissinger's efforts culminated in Smith's public announcement that he would accept majority rule within two years. This set the stage for the later Lancaster House negotiations which resulted in the actual transition to black majority rule. The account in this working paper carefully describes - but does not analyze nor draw lessons from - these challenging negotiations. Forthcoming papers will provide analysis and derive general insights from Kissinger's negotiations to end white minority rule in Rhodesia.
\end{abstract}

"it would not have been predicted by any observer of American politics that a Republican administration would take the lead in bringing about the breakthrough to majority rule in Southern Africa. Majority rule had been a liberal cause, never translated into an operational policy." 1

- Henry Kissinger

"I don't believe in black majority rule ever in Rhodesia, not in a thousand years." Thus vowed Ian Smith, Rhodesia's white Prime Minister, on March 20, 1976. ${ }^{2}$ Outnumbered 22-1 in that Southern African country, some 270,000 whites had defiantly ruled over six million blacks since Smith unilaterally declared Rhodesia's "independence" from Great Britain just over a decade earlier.

Since "independence" - that no country in the world had recognized - intensive British diplomatic efforts at the highest levels had utterly failed to persuade the intransigent Smith to accept black majority rule. Despite this history, Henry Kissinger had initiated complex coalitional negotiations in the region during the waning year of Gerald Ford's administration. Scarcely six months after Smith's "not in a thousand years" declaration, Kissinger had orchestrated an about-face by the Rhodesian Prime Minister. Stunning his white countrymen - and a world audience - Ian Smith made a televised announcement, accepting the principle of majority rule for his country, to take effect within two years. ${ }^{3}$

More surprising was how Kissinger had engineered Smith's turnabout. By delicately working with both moderate and radical black African states, he had persuaded a most reluctant South Africa - that "citadel of apartheid" - to apply decisive pressure on neighboring Rhodesia to abandon its policy of white minority rule. ${ }^{4}$ Remarkably, South Africa had agreed to bring this pressure despite the plain fact that, if Rhodesia capitulated, anti-apartheid forces would - and later did - shift their main energies toward South Africa, the major remaining white-ruled state in the region.

\footnotetext{
* James K. Sebenius (jsebenius@hbs.edu) is the Gordon Donaldson Professor of Business Administration at Harvard Business School; R. Nicholas Burns (Nicholas_Burns@hks.harvard.edu) is the Roy and Barbara Goodman Family Professor of the Practice of Diplomacy and International Relations at the Harvard Kennedy School of Government; Robert H. Mnookin (mnookin@law.harvard.edu) is the Samuel Williston Professor of Law at Harvard Law School; and L. Alexander Green (lgreen@hbs.edu) is a Research Associate at Harvard Business School. This working paper is based on, and draws from, a forthcoming book by Sebenius, Mnookin, and Burns entitled, "Kissinger the Negotiator: Lessons from Dealmaking at the Highest Level," as well as a concurrent working paper entitled, "Henry A. Kissinger: Background and Key Accomplishments," by James K. Sebenius, L. Alexander Green, and Eugene Kogan.
} 
At the time, this was big news. Time magazine's cover story on October 11, 1976 lauded Henry Kissinger's "dazzling diplomatic foray into Southern Africa" that "raised the possibility that Rhodesia - as well as much of the rest of southern Africa - might be poised on the brink of peace instead of a race war that was once thought inevitable." ${ }^{5}$ Along with much of the world's press, the British Observer gushed that this intricately choreographed process represented "a staggering diplomatic coup" in a "seemingly intractable crisis." 6

Though Ian Smith's reversal would prove pivotal, black majority rule in Rhodesia would not come on Kissinger's watch. When Gerald Ford lost the 1976 Presidential election soon after Smith's announcement, Kissinger became a lame duck. This effectively ended his role in the negotiations, which stalled, triggering an upsurge in guerilla fighting and diplomatic activity. Majority rule in Rhodesia became a reality with a 1979 agreement that largely followed the Kissinger blueprint and was forged under British leadership at London's Lancaster House.

Henry Kissinger had confronted a range of negotiating challenges over almost eight years under two presidents. These included the opening to China, the end to the Vietnam war, détente and arms control with the Soviets, as well lasting disengagement accords among Egypt, Israel, and Syria following their 1973 war. Yet Kissinger declared, "Of all the negotiations I conducted, by far the most complex was the one over majority rule in Southern Africa [italics added]."7

Henry A. Kissinger, Negotiator. Henry Kissinger is a statesman, scholar, and public intellectual. Born in 1923 to a German Jewish family in Fürth, he emigrated from Germany to the United States in 1938 to avoid "state sanctioned anti-Semitism" by the Nazi government. ${ }^{8}$ He became a naturalized United States citizen in 1943 and served in the Army from 1943 to 1946, seeing action in the European theater. After completing his education at Harvard (BA summa cum laude 1950, M.A. 1952, and Ph.D. 1954), he served as a faculty member in Harvard's Department of Government and its Center for International Affairs from 1954 to $1969 .{ }^{9}$

Kissinger served as foreign policy advisor to New York Governor Nelson Rockefeller, who three times sought the Republican nomination for President. ${ }^{10}$ Despite his support of Rockefeller, a political rival, President Richard Nixon selected Kissinger to serve as his Advisor for National Security Affairs from January 20, 1969 to November 3, 1975. While National Security Advisor, Kissinger was also sworn in as the 56th Secretary of State on September 22, 1973. ${ }^{11}$ After the Watergate scandal led to Nixon's resignation, Kissinger continued to serve as Secretary of State under President Gerald Ford until January 20, 1977.

Throughout his time in office, Kissinger exerted a strong influence on American foreign policy. He took the lead in conceptualizing and implementing the policy of détente with the Soviet Union, intended to relax dangerous tensions between the two nuclear superpowers. ${ }^{12}$ As part of this process, he negotiated the Strategic Arms Limitation Talks (resulting in the SALT I treaty) and the Anti-Ballistic Missile Treaty.

In tandem with working for détente with the Soviet Union, he played a central role in helping to end over years of diplomatic isolation and mutual hostility between the United States and China. Culminating in the 1972 summit among Richard Nixon, Zhou Enlai, and Mao Zedong, this initiative led to formal relations between the two countries, helped the United States make progress in extricating itself from Vietnam, and transformed U.S.-Chinese-Soviet relations into a form of "triangular diplomacy."

By 1973, following prolonged secret negotiations between Kissinger and Le Duc Tho, North Vietnamese politburo member, the Paris Peace Accords were signed. Intended to end the Vietnam war, this agreement led to a (temporary) ceasefire and was followed by the cessation of direct U.S. military involvement. In violation of the major provisions of this agreement, North Vietnam conquered the South in April 1975. (Le Duc Tho and Kissinger were jointly awarded the Nobel Peace Prize, which Le Duc Tho refused to accept and Kissinger later sought, unsuccessfully, to return.) 
Following the October 1973 Yom Kippur war among Israel, Egypt, and Syria, Kissinger engaged in an intensive process of "shuttle diplomacy." His efforts over eight days in January 1974 led to an initial EgyptianIsraeli disengagement accord, followed by a Syrian-Israeli disengagement in May of that year, and a second Egyptian-Israeli disengagement agreement in September 1975.

Kissinger has been involved in many other foreign policy initiatives and negotiations. He received the Presidential Medal of Freedom in 1977 and the Medal of Liberty in 1986. He is a prolific author of 21 books and countless articles, and a recipient of the National Book Award for the first volume of his memoirs, White House Years. Since leaving office, Kissinger has served as Chairman of Kissinger Associates, a strategy consulting firm, and has been in demand publicly and by a range of national and business leaders for his analysis and advice on challenging foreign policy issues. ${ }^{13}$

Southern Africa: The Lay of the Land. "Southern Africa," the region, and "South Africa," the country, can be easily confused. To clarify, Kissinger's negotiations focused on three white-ruled entities. [See the map below.] In 1975, these included:

$>$ South Africa, an increasingly isolated but regionally dominant country in which some four million whites, among a population of roughly 22 million at the time, had instituted apartheid, a policy of segregation by race that imposed severe civil, legal, and economic restrictions on non-whites and denied them many rights afforded to white citizens.

$>$ Rhodesia was a former British colony later known as Zimbabwe, in which, as noted above, some 270,00 whites controlled some six million black Africans. Rhodesia had illegally declared independence in 1965 under the leadership of Ian Smith, a Royal Air Force fighter pilot in World War II. No other country had recognized this defiant, pariah state, which was subject to comprehensive U.N. economic sanctions, and under increasing military pressure from guerilla forces seeking to topple its white regime.

$>$ Namibia, a former German colony known earlier as South-West Africa, was administered by South Africa under a limited mandate from the League of Nations after World War I. While the United Nations later revoked this mandate, South Africa continued to govern this large territory of less than a million inhabitants as its de facto "fifth province."

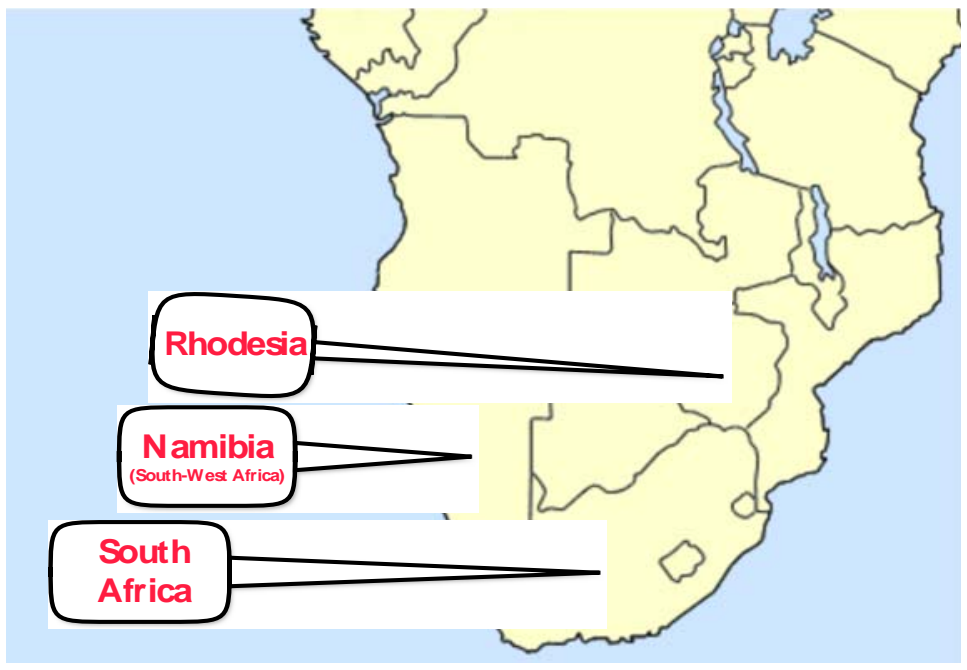

Three White-Ruled Regimes in Southern Africa (1975) 
Fears of An African Front in the Cold War, Crisis in Angola, and the Failure of a Covert Response. Dramatic photos of helicopters evacuating desperate Vietnamese and Americans from Saigon on April 29, 1975 dominated U.S. front pages as a brewing crisis in Southern Africa began to engage the White House. Relatively neglected by American diplomacy, this region assumed a new importance during the last 18 months of the (Republican) Ford administration as Angola and Mozambique, both newly independent from Portugal, began to fall under Marxist sway.

The first indication that the Cold War might be coming to Southern Africa occurred in 1974 when a left-wing coup in Portugal spurred the hasty demise of colonial domination of Mozambique. A Marxist group rapidly gained power in that East African country, which declared independence in 1975. On an April state visit to Washington, Zambian President Kenneth Kaunda warned of a growing Marxist insurgency in neighboring Angola as the Portuguese colonial power departed that nation. This Angolan insurgent group had increasingly been supported by significant military aid from the Soviet Union and what would ultimately amount to some 20,000 Cuban combat troops. In part, these movements merely joined many other African countries that had been ousting their former European colonial masters since Ghana gained its independence in 1957. But through Cold War eyes, by early 1976, two important coastal nations in Southern Africa - Angola on the west coast and Mozambique on the east - were fast falling under Soviet influence.

In the contest for influence and resources that characterized the Cold War, a Soviet-sponsored Cuban alliance with African Marxists alarmed Kissinger and Ford - as well as many leaders of newly decolonized African nations in this region from Tanzania and Zambia to the white regimes of Rhodesia and South Africa. Unless effectively opposed, Soviet-Cuban insurrections could spread via direct intervention as well as by support of favored guerilla groups in different countries. [See fuller map below, which also shows the "frontline states" that surrounded white-ruled Rhodesia.] Even if the prime targets of such guerilla groups were the white-ruled regimes, their presence in neighboring countries, such as Zambia and Tanzania, could destabilize and even overthrow such fragile "host" governments. U.S. inaction could cede dominant influence over this mineral-rich region to the Soviets. More broadly, Ford and Kissinger judged that an ineffectual U.S. response would vividly demonstrate the post-Vietnam loss of American will -in the midst of the Cold War that then dominated geopolitics, despite détente.

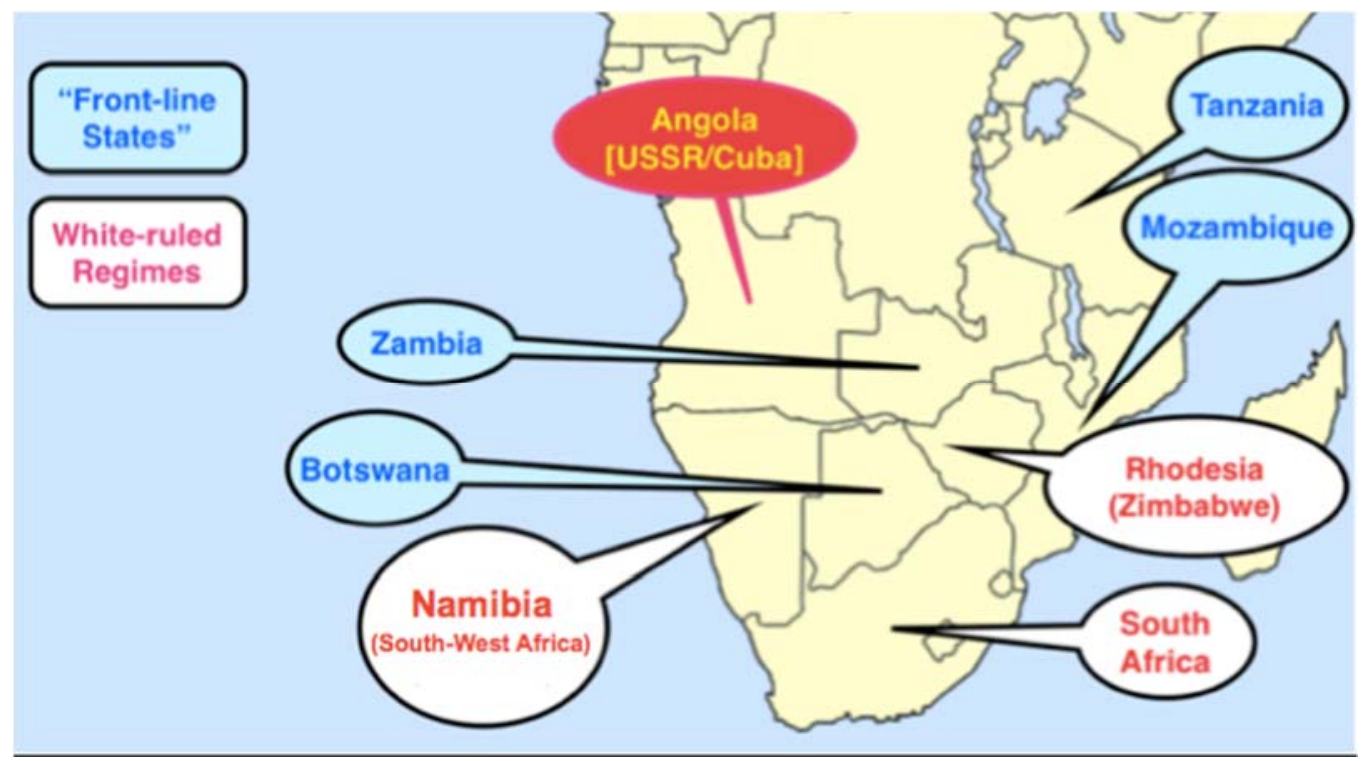

White-ruled and "front-line" states, plus Angola (1975)

Beyond geopolitics, there was widespread, almost fatalistic, talk about a coming "race war" in Southern Africa, especially Rhodesia. For example, a 1976 Associated Press dispatch stated "Most worrying to whites is the prospect that Soviet arms and Cuban troops in Angola might be used in Rhodesia to back militant black movements in a conflict that could spill over borders to engulf the entire region. Neighboring 
black-ruled states - Tanzania, Angola, Mozambique, and Zambia - all have warned a racial ‘bloodbath' is imminent in Rhodesia."14

Kissinger had multiple, entangled motives for acting in Southern Africa: to prevent Cold War rivals from dominating the region, to advance democratic principles by promoting black majority rule, and to avert a race war. His early actions prioritized Cold War geopolitics: to counter the Soviets and Cubans in Angola he orchestrated a covert military operation with French help. While he kept the Congress quietly informed, public revelation of these covert plans rapidly led to a U.S. law banning them entirely. In any event, with the covert route firmly blocked and military options effectively off the table, Kissinger pondered alternative strategies.

Crafting a Negotiation Strategy. Kissinger came to believe that the Soviet/Cuban threat could be weakened if American diplomacy could persuade the nations of Southern Africa to rebuff any foreign intervention in the region. As he observed, "If we wanted to resist future Soviet and Cuban adventures in Southern Africa and to reduce and expel Soviet and Cuban influence there - as we had in the Middle Eastour policy would have to reflect the aspirations of the vast majority of the continent."15

Existing moderate American policy toward Rhodesia and South Africa had been (insensitively) dubbed the "Tar Baby option."16 The secret Nixon Administration document that adopted this policy noted that "We would maintain public opposition to racial repression but relax political isolation and economic restrictions on the white [ruled] states."17 Kissinger's new approach-persuading states in the region to rebuff foreign intervention - would require abandoning the "Tar Baby option" in favor of actively supporting black majority rule in Rhodesia and Namibia. ${ }^{18}$

To further this goal, Kissinger hoped to orchestrate negotiations that would put Rhodesia and Namibia on a clear path to black majority rule on fixed timetables. Apart from South Africa, all states in the region passionately desired this outcome. Yet it had long seemed out of reach. Since 1965, Britain had actively sought to persuade the white Rhodesian regime not to declare independence and to accept black majority rule. Dramatizing British power, Prime Harold Wilson twice summoned Ian Smith to the decks of two British warships, the Fearless and the Tiger, for direct, high-level negotiations. These talks had utterly failed, leading the British to largely abandon their efforts and want nothing more to do with Smith. ${ }^{19}$ Whether conviction or bluster, Rhodesian Prime Minister Smith's uncompromising position - no black majority rule in Rhodesia "in a thousand years" - reflected the reality that, if the black majority ruled in Rhodesia, the political and economic power enjoyed by the white minority would inevitably suffer.

How to Negotiate with Ian Smith? Imagine how one might most effectively negotiate with Ian Smith, Rhodesia's white leader, to persuade him to accept majority rule within two years. Naturally, one would look into Smith's background, finding that he was born in 1919 of Scottish immigrants on a farm in Rhodesia, preferred sports to academics in school, was downed twice and injured as a British Royal Air Force pilot in the Second World War, partially paralyzing his face into what many observers saw as an permanently stern expression. Smith entered politics, declared Rhodesia independent from Britain, styled his country as a "front line against international Communism," and professed "The white man is master of Rhodesia. He has built it, and he intends to keep it." 20 And, as Kissinger observed, the British "detested Ian Smith, believing he had deceived and embarrassed them, first by declaring independence and then in the course of a number of stalemated negotiations." 21

Assuming one enriched this skeletal profile of Smith with deeper psychological and background research, what negotiating approach would offer the best chances for success? Following the lead of British diplomats and the Prime Minister himself over the decade since Rhodesia declared independence, a merely competent negotiator facing this challenge might start by setting up a high-stakes meeting with Ian Smith in a carefully chosen location. Then face to face with Smith, by some combination of flattery, a steely gaze, vague 
warnings or threats, historical argument, and a silver tongue, our negotiator might seek to persuade the defiant leader to offer some form of majority rule to Rhodesia's black citizens.

Not Henry Kissinger. During a news conference on September 5, 1976, when asked about even the "possibility of meeting" with Smith, Kissinger replied "I have no present plans to meet with Mr. Smith and this would depend entirely on assurance that a successful outcome of the negotiations will occur." 22 His blunt assessment: "All previous efforts had failed because they had started with negotiations with this representative of a white minority that had no conceivable incentive to abandon its dominance [italics added]." 23

Assessing the Situation: Parties, Interests, Resources, and Barriers. Mindful that his would be the first substantive (non-ceremonial) visit to Southern Africa by a U.S. Secretary of State in American history, Kissinger assessed the situation, especially the interests of the varied stakeholders, his resources in a potential negotiation, and the barriers to be overcome. Here, mainly in his own words, is his assessment:

“Before launching ourselves into Africa, we needed to distill a strategy from the partially overlapping, partially incompatible objectives of the various parties. Our principal asset was that the African states themselves were urging us to become involved while the white minority governments trusted us more than any other country or, for that matter, any alternative leadership group in the United States. As for the other parties or potential parties:

$>$ The "front-line states" - the countries bordering or close to Rhodesia: Mozambique, Zambia, Tanzania, and Botswana - on whose territory the guerrillas were organizing, were the conduit for arms from outside the continent and for foreign advisers or Cuban troops. [See map above.] But their leaders also knew that the Rhodesian forces were well armed and tough. A war would be costly and might well end with the guerrilla forces ceasing to be guests and instead dominating the host country.

$>$ The other African states, less immediately engaged, supported majority rule in principle but were prepared to cooperate in preventing the continent from becoming a battleground of the Cold War.

$>$ South Africa [longtime supporter of Rhodesia] feared that armed struggle in Rhodesia might turn into the prelude to an assault against South Africa itself. At the same time, all the front-line states recognized that South African assistance was indispensable to a Rhodesian solution, for, without it, the transition would be bloody, the outcome uncertain, and the radicalization of the whole region inevitable.

$>$ For Britain, Rhodesia represented a painful reminder of the diminution of its international status. Britain's inability to force Rhodesia into submission weakened its effort to develop a new African role based on cooperation with its former colonies. It explains as well the personal hatred many British leaders felt for Ian Smith, which complicated and often frustrated British dealings with him.

$>$ As for the Rhodesian authorities, they had the least to gain .... Whatever guarantees of minority rights might be associated with majority rule, the position of the European population would inevitably atrophy.... The Ian Smith authorities could be induced to settle only by having it brought home to them that the policy we were fashioning was the least distasteful of the painful choices before them." 24

From this assessment of the African and British parties, Kissinger crystallized a key part of the negotiating challenge: "This maze of incommensurables - that those with power had no legitimacy and those with legitimacy no power, that the passions of the parties were matched by their distrust of each otherdefined both the limits of our African strategy and its prospects." 25

Finally, Kissinger had to consider the politically treacherous division on the home front. In the United States, the hard-fought advancement of civil rights over the previous fifteen years made minority white-ruled regimes and apartheid especially controversial. Believing that the increased pressure of sanctions would hasten the demise of apartheid, one group, generally liberal in political orientation, advocated more isolation and pressure. An opposing group, generally conservative, believed that the normalization of relations with 
South Africa would over time moderate the white minority government's policies. Sanctions and excessive pressure on these regimes, this more conservative group argued, risked abandoning whites to what could easily devolve into a bloody race war, countries hostile to the West, and regional anarchy.

This longstanding divide in U.S. politics took on new intensity as imminent Republican primaries pitted conservative icon, Ronald Reagan, against Gerald Ford, the incumbent President who had succeeded Richard Nixon. Already suspicious of Kissinger, détente with the Soviets, and the opening to China, many Republican primary voters opposed policies that seemed to favor black majority rule in Rhodesia and South Africa. Yet Kissinger had a stalwart backer in President Ford, who consistently took the high ground: "I cannot judge whether the political impact will be good or bad. But we must do this because it is the right thing to do." 26

From this assessment of the parties and their interests, Kissinger needed to craft a strategy that would overcome the reason for prior failures: "Previous efforts had failed because they could not generate the balance of rewards and penalties to reconcile the conflicting motivations comprising the cauldron of Southern Africa." 27

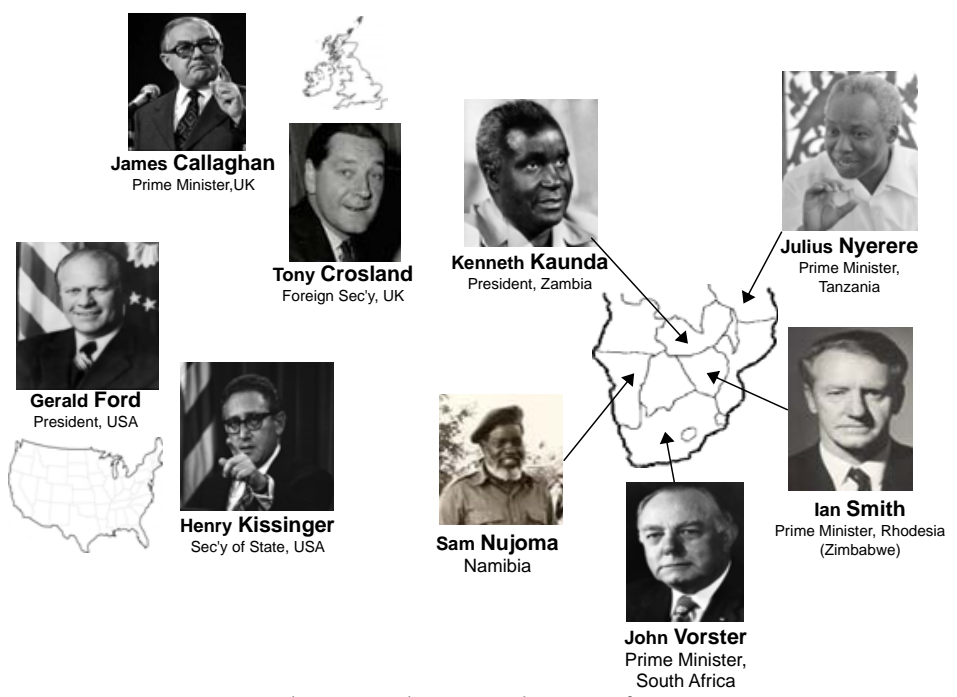

Some Key Leaders in the Southern Africa Negotiations

A Six-Part Negotiation Strategy. ${ }^{28}$ To generate the favorable balance of rewards and penalties that had eluded prior negotiators, Kissinger began to, develop "a coherent strategy for breaking the deadlock once and for all." 29 The strategy to guide his actions - in close concert with his handpicked team-encompassed six broad elements:

First, it would offer, "... the front-line states a shortcut to majority rule by throwing the weight of American diplomacy behind their goals. They would be spared the destruction attendant on a prolonged struggle and the risk to their domestic stability of establishing large guerrilla units on their soil...." In return, Kissinger would insist ". . . that they keep foreign forces out of the conflict, assume responsibility for the negotiating positions of the Rhodesian liberation movements, and guarantee [white] minority rights...."

Second, Kissinger would work “. . closely with moderate African leaders, especially in Kenya, Zaire, Senegal, and the Ivory Coast, to help shape a consensus in the [Organization of African Unity or] OAU supportive of our policies and to protect the frontline Presidents from radical African and international pressures..."

Third, Kissinger would count "... on Britain to reenter the diplomacy in Southern Africa and to play an important role in the constitutional conference that would be the culmination of the breakthrough we hoped to achieve." 
Fourth, to South Africa's leaders, Kissinger would convey “... that they would be given a responsible role in helping shape an Africa of peace, stability, and racial justice. South Africa would be treated as a valuable interlocutor and given a breathing space in dealing with its own problems provided it helped move Southern Africa toward a new political dispensation. ..." But, Kissinger emphasized, we would make "... it very clear that our support of majority rule did not stop at the borders of South Africa...."

Fifth, as noted above with respect to Rhodesian leader, Ian Smith, Kissinger observed “. . . All previous efforts had failed because they had started with negotiations with this representative of a white minority that had no conceivable incentive to abandon its dominance. We therefore proposed to deal with Smith only after the other parties' commitments had been agreed. We could do nothing about the reality that Smith and his European minority had little to gain from our diplomacy. But we proposed to ease the transition by treating him with respect. I had no record with him either for good or ill and considered him a problem to be dealt with rather than an enemy to be overcome. ..."30

Sixth and finally, throughout this process, Kissinger would maintain a focus on the domestic front: "As we ventured into heretofore uncharted territory, we made a major effort to build domestic support." 31 This involved extended consultations with Congress, meetings with influential African-American leaders, and, critically, nurturing and relying on support from the most important relationship of all for a U.S. Secretary of State: the President.

A simplified version of Kissinger's intended sequence would be to 1) obtain a domestic mandate, 2) consult with Britain over the issue and its provisional role in the negotiations, 3) bring front-line states on board, 4) pitch the more distant African states, 4) persuade South Africa to pressure Rhodesia, 5) negotiate with Rhodesia to accept the principle of majority rule with a timetable, 6) finalize British support, and 7) rely on the United Kingdom to orchestrate a conference at which all the relevant parties would negotiate the full regional terms of this outcome.

While Kissinger would be the principal soloist and conductor for this sequential negotiation campaign, orchestrating such a complex strategy required a skilled ensemble. Almost continuously, in cables and in person, Kissinger relied on his team to provide him with information and updates, to convey messages to the various players, and to help maintain momentum on multiple fronts. ${ }^{32}$

From Strategy to Execution, the Opening Stage of a Negotiation. "Phase One" of Kissinger's strategy called for gaining at least provisional support from the United States, Britain, and the front-line states. This approach, developed with President Ford's concurrence, rested on a fundamental U.S. reorientation of its policy toward Southern Africa. Kissinger: "On March 13, Ford for the first time committed the United States to unequivocal support for majority rule in Southern Africa: [in the President's words] 'The United States is totally dedicated to seeing to it that the majority becomes the ruling power in Rhodesia.'"33 Ford later underscored a key motive: "Political stability [in Southern Africa] was crumbling everywhere and it was imperative to send Henry Kissinger to the continent to see if he could head off a race war." 34

Kissinger closely aligned his early planning with the British, who were grappling with an economic downturn, frustrated by years of unproductive attempts to get Smith to relinquish power and reluctant to being drawn into a possible military entanglement. Nevertheless, British Foreign Secretary James Callaghan outlined the conditions by which the United Kingdom would support a revived attempt to reach a peaceful settlement in the region:

[F]irst, acceptance of the principle of majority rule; secondly, elections for majority rule to take place in 18 months to two years; thirdly, agreement that there will be no [recognized] independence [for Rhodesia] before majority rule; fourthly, the negotiations must not be long drawn out. ${ }^{35}$ 
Kissinger felt that securing British backing and adopting elements of Callaghan's framework would be a political and legal asset. Britain's role as the former colonial power would add international support and give Kissinger insights into the region beyond those that State Department's newly reformed African Bureau could provide. In addition, any Rhodesian agreement would have to conclude with the creation of a constitution and a legal transfer of power. Since Smith's regime had no international standing, Kissinger believed that the British would have to oversee that effort to ensure its legitimacy.

After reaching a general understanding with the British on the role they would play in the process, Kissinger planned an unprecedented visit during April 1976 to meet with African leaders face-toface, shoring up support with powerful members of the Organization for African Unity. ${ }^{36}$ The focal point of his trip would be a speech in Lusaka, Zambia that would publicly unveil the new United States policy of support for majority rule. Kissinger intended his remarks to go far beyond simply expressing shared values with the leaders of the front-line states. He would outline specific steps and conditions, aligned with Callaghan's four points, that he believed were necessary to usher in black African leadership in Rhodesia and Namibia. ${ }^{37}$

The Africa Trip and "Zooming in" on Julius Nyerere. Kissinger first visited Kenya to describe his initiative to Jomo Kenyatta, its widely respected President, and seek Kenyatta's support. From Kenya, he flew to meet with President Julius Nyerere of Tanzania, a key member of the front-line states and central figure in the Non-Aligned Movement of developing countries that sought a political path independent of East and West.

As an example of how Kissinger "zooms in" on his negotiating counterparts as individuals, Kissinger's interactions with Nyerere will be recounted in greater detail than will be the case with several other leaders such as Kenyatta. Kissinger described Nyerere as ". . a slight, wiry man, [who] invited me to his modest private residence. ... He was graceful and elegant, his eyes sparkling, his gestures fluid. With an awesome command of the English language (he had translated Julius Caesar into Swahili), Nyerere could be a seductive interlocutor. But he was also capable of steely hostility.... He took pride in his chosen role as "Mwalimu" (the "teacher") of his people. ${ }^{38}$

A supporter of the militant rebel faction led by Robert Mugabe in Rhodesia and the South-West Africa People's Organization (SWAPO) guerilla movement in South-West Africa, Nyerere was also thought to be allied with Mozambique's radical Marxist President Samora Machel, and opposed to the moderate Kenneth Kaunda in Zambia. Despite these ideological differences and Nyerere's ingrained suspicion of American policy, Kissinger developed a rapport with the Tanzanian President, who "... was his own man. His idiosyncratic blend of Western liberal rhetoric, socialist practice, nonaligned righteousness, and African tribalism was driven, above all, by a passionate desire to free his continent from Western categories of thought, of which Marxism happens to be one. His ideas were emphatically his own. I got along with the front-line Presidents, including and especially Nyerere, because I took them seriously. I met them on their own terms and did not treat them - as did so many of their admirers in the West - as extensions of Western preconceptions. ${ }^{39}$

Nyerere proved to be an adept sparring partner for Kissinger. David Martin, the Observer's longtime Africa correspondent, wryly observed "One began a quote from Shakespeare ... or a Greek philosopher and the other would end the quotation. Then Nyerere quoted an American author. Kissinger laughed: Nyerere knew Kissinger had written the words." 40

The two soon found a shared pragmatism and a desire for stability. Despite his radical leanings, Nyerere concurred with Kissinger's regional assessment that recent Cuban success in Angola might lead to the involvement of Cuba's troops elsewhere in the region, potentially destabilizing existing regimes. While the front-line presidents agreed on the imperative of ending minority rule in Rhodesia, significant disagreements existed between them about how it should be accomplished. Nyerere agreed to advocate for an American-backed peace initiative, later commenting "We want the two greatest sources of power on our side - God and Kissinger." 41 
Kissinger did not take Nyerere's support as unconditional. "To Nyerere, the United States was a weapon to be employed to accelerate the liberation struggle. For this, he was prepared to pay some price in moderating his colleagues. More reluctantly, he was prepared to grant some rights to the white minorities, and, even more reluctantly, to exclude Cuban participation in the struggle." 42

As Kissinger departed, he believed he had found in Nyerere an important ally and the key to gaining the support of the front-line states. Nyerere would be "... the bridge between such moderates as Zambia's Kenneth Kaunda and Botswana's President Seretse Khama on one side, and the radicals ... in the former Portuguese colonies of Mozambique and Angola on the other. ${ }^{43}$

The Lusaka Speech. Arriving in Lusaka, Zambia, after his negotiations with Nyerere, Kissinger met with President Kenneth Kaunda. To regional leaders assembled in Lusaka, Kissinger made a major speech on April 27 outlining his plan to jumpstart negotiations in the region. Declaring Smith's regime and the South African occupation of Namibia illegal, he urged both governments to present timetables for handing over power and establishing majority rule.

Kissinger described measures by which the United States would further isolate Smith while assisting the front-line states. He would commit the United States to tripling its funding for development initiatives in sub-Saharan Africa. Financial support would be arranged for Mozambique. Efforts would be made to provide aid to refugees displaced by the increasing violence that stemmed from Smith's refusal to abdicate power. He urged American citizens to leave Rhodesia immediately and avoid travel to the country. He announced that he would seek the repeal of the 1971 "Byrd Amendment" that had allowed the United States to circumvent the UN embargos on key Rhodesian products, and had drawn sustained international condemnation. ${ }^{4}$

Referring to Rhodesia as Zimbabwe - the name preferred by black Africans - Kissinger assailed the separation of races and called for equal rights in an independent nation. "So let it be said," he concluded, "that black people and white people working together achieved on this continent, which has suffered so much and seen so much injustice, a new era of peace, well-being, and human dignity." 45

Widely covered internationally, the Lusaka speech expressed a momentous shift in American policy that was immediately evident to those present. When Kissinger finished speaking, Zambian President Kenneth Kaunda "rose to embrace me: 'Some of us,' he said 'were so emotionally charged when you were speaking. We could not believe this was a Secretary of State from Washington, D.C.'" 46 Kaunda delivered an immediate, impromptu response on behalf of the front-line state leaders, telling Kissinger to "assure President Ford of our support." 47

From Lusaka to Nairobi. "With the Lusaka speech, our African strategy was falling into place: first, agreement with front-line states on an overall strategy for Southern Africa; next, a visit to key Central and West African countries to reassure them about America's staying power and to enlist their support in African forums." 48 He sought backing for his efforts across the entire continent, especially given the close connections between many African leaders, forged during their shared struggles for independence from colonial rule. ${ }^{49}$

Kissinger ended his trip at the fourth U.N. Conference on Trade and Development in Nairobi, Kenya, with promises of American economic commitments to Africa, putting them in the context of global growth..$^{50}$ By the time Kissinger arrived in the Kenyan capitol, Tanzanian President Nyerere had gained initial support among the front-line states for the American initiative. ${ }^{51}$

The Domestic Front. Shortly after the Lusaka speech, Gerald Ford was catastrophically defeated by Ronald Reagan in the Texas Republican primary on May 1, 1976. Kissinger's efforts had inflamed conservatives. As CBS news radio reported, "Reagan quickly picked up Kissinger's new theme in Africa, and accused the Secretary of preparing a bloodbath in Rhodesia." 52 Kissinger observed "Some political experts subsequently claimed that it was our support of majority rule-interpreted as abandonment of the white populations of Southern Africa - that had transformed Ford's probable setback into a debacle."53 
Along with the sentiments expressed in primary voting, the State Department received 1700 letters opposing Kissinger's speech and only 23 in support of it..$^{54}$ Kissinger redoubled his efforts to blunt domestic criticism of his initiative by meeting with as many U.S. stakeholders as possible and regularly briefing key members of congress. ${ }^{55}$

For example, he consulted with about thirty African-American leaders to explain his goals, understand their concerns, and seek their support. 56 The Reverend Jesse Jackson, concluded one of four such meetings by stating "No other Secretary of State has accorded such respect to the black American community ... We support the African policy that you have enunciated. You have our support on this. Other Secretaries of State would not have met with us as you have." 57

Most importantly for the initiative of an American Secretary of State, Kissinger cultivated and enjoyed unwavering support from President Ford, despite the political consequences for his re-election prospects. ${ }^{58}$ During Kissinger's mission, Ford issued the following statement to the press: "The President makes foreign policy, and Dr. Kissinger carries out and enunciates that foreign policy, and that is what he has done on the African trip." 59 On Kissinger's return to Washington, Ford held - and made a point of publicizing - high-profile meetings with his Secretary of State about the African initiative, one with the National Security Council and another at the White House with bipartisan Congressional leadership. 60

Gaining South African Agreement. By May 1976, Kissinger had obtained a U.S. mandate for his Southern African strategy along with at least provisional support from the front-line states and other key African nations as well as from the United Kingdom. The next vital ingredient in his strategy was to negotiate for South African pressure on Ian Smith in order to induce the Rhodesian leader to agree to majority black rule on a tight timetable. South Africa had provided vital economic and military support to Rhodesia as well as key transport links and access to the rest of the world, especially valuable when Mozambique closed its border to Rhodesia in March 1976. "Incongruously, pariah South Africa, the citadel of apartheid, was emerging as the key to progress toward majority rule in Southern Africa. All black African leaders castigated it, and all of them urged us into a dialogue with South Africa's leaders."61

At first blush, the prospect of white minority ruled South Africa pressing white minority ruled Rhodesia to accept black majority rule must have seemed inconceivable. If the white regimes in Rhodesia and Namibia lost power, South Africa would stand "alone without any buffer to face an Africa united in its demand for an end to apartheid .... [S]ooner or later such demands were bound to become irresistible ..." 62

Despite the almost certain prospect that South African pressure on Rhodesia for majority rule would boomerang, Kissinger could craft his persuasive appeal to South African Prime Minister Johannes ("John”) Vorster on the basis of at least three related factors.

First, South Africa was becoming far more isolated internationally, partly as a result of international opprobrium and sanctions as well as U.S. actions. For example, in January 1976, the United States voted in favor of a U.N. resolution demanding that South Africa set a timetable for ending its illegal occupation of Namibia. ${ }^{63}$ Two months later, another resolution passed - again, with American support - this time condemning South Africa's military involvement in Angola. ${ }^{64}$ Weeks later, Kissinger's Lusaka speech set forth explicit demands that South Africa take steps to dismantle apartheid.

Second, South Africa faced worsening economic conditions, rising threats of domestic instability, and a deteriorating military outlook on its borders. ${ }^{65}$ Exacerbated by international isolation and sanctions, its economy was in steep decline, suffering from the combined effects of a worldwide energy crisis and the loss of regional trade that had accompanied the recent closure of the Mozambique border. ${ }^{66}$ Demands for military support outpaced the government's ability to pay for them, depleted by the increasing costs 
of fighting guerillas in Namibia, securing the borders, managing internal state security, and supporting Ian Smith's regime. ${ }^{67}$

Third, from South Africa's standpoint, an agreement for majority rule Rhodesia might forestall yet worse outcomes. Kissinger made a fundamental judgment: "Rhodesia and Namibia had turned into liabilities for South Africa internationally and a drain on its resources. ... What South Africa's leaders sought to avoid was to be obliged to stand by while the white minority in Rhodesia was being overrun militarily by black guerrillas. And no doubt they hoped to create successor regimes in both Rhodesia and Namibia which, though black, would stem the radical tide before it could reach South Africa's borders." 68

Mindful of these factors, Kissinger offered the South Africans an unprecedented meeting in Europe, leaving open the possibility of a later visit to South Africa itself. Kissinger underscored the significance of U.S. willingness to visibly lessen South Africa's deepening isolation: "No American Secretary of State had been prepared to meet South African leaders in over thirty years, much less to negotiate with them - even in world forums like the U.N. I was, in effect, offering South Africa a role in shaping the future of Southern Africa in return for a commitment to majority rule in the neighboring countries and ultimately in their own. ${ }^{69}$ Boosting the appeal of Kissinger's offer, President Ford publicly indicated that "[I]f at some point it would seem wise to meet with the two heads of Rhodesia and South Africa, I certainly would."70

On June 16,1976, as the date for the Vorster-Kissinger meeting approached, a protest by blacks in the township of Soweto prompted a violent response by the South African government. Over four hundred civilians were killed, sparking months of protests in the black townships. ${ }^{71}$ The United States joined the United Nations in condemning the South African government's violent and disproportionate crackdown.

In the face of this sharply intensified international criticism, Kissinger's continued willingness to meet Vorster in Germany - despite the virtual certainty of thousands of anti-apartheid protesters became even more valuable to the South Africans.

Finally, on June 23, face to face with Vorster "in a smallish sitting room, I began - as was my habit in almost all negotiations - with a philosophical discussion of what we were trying to achieve."72 For both geopolitical and moral reasons, the United States was seeking peaceful transitions to majority rule in the region. But, Kissinger argued, "If Vorster identified the future of his country with the fate of Rhodesia and Namibia, the outcome would be complicated and surely considerably delayed. But in the end, majority rule was unavoidable in Rhodesia ... Violence would increase; radicals would gain control of the armed struggle, aided probably by foreign forces, at which point South Africa would face the dilemma of holding still while the European populations of Rhodesia and Namibia were expelled or joining the conflict. ${ }^{73}$

However, by working with the Americans, Vorster could draw "a distinction between his northern neighbors and South Africa based on the reality that South Africa was considered even in Africa as an African, not a colonial, country - however resented its domestic institutions were. This point had been stressed by every African leader I had encountered. . . . The opportunity I was offering Vorster was to achieve a certain breathing space in which his country might solve its problems peacefully, not a means for escaping them."74.

Kissinger neither threatened the South Africans nor lectured them. The Ford Administration was not "waging a crusade against them as individuals; indeed, ... we had compassion for the agonizing dilemmas bequeathed them by preceding generations. . We were not out to punish them for their fathers' sins or even their own - as were so many of their critics in the West. Rather, our goal was to bring 
them face-to-face with their realities and lead them as gently as possible to the acceptance of the fact that these dictated change both on moral and on political grounds."75

South African Prime Minister Vorster, with a notably hardline record, proved responsive to this combination of tone and arguments. His "entire bearing suggested that, faced with a superpower which treated them with some consideration, the Afrikaners were not circling their wagons as they had been obliged to do too often in their difficult history."76

In general terms Vorster agreed to help promote change in Rhodesia and Namibia based on selfdetermination. "Provided he was not being asked to abandon Rhodesia's European population without any rights, he would support our efforts to produce majority rule in Rhodesia. He agreed that a moderate outcome in Rhodesia was possible only if the armed struggle was brought to an early end."77

"It was a measure of both their isolation and sense of foreboding that the South Africans should have accepted so readily the only quid pro quo I could offer in exchange for their cooperation on Rhodesia and Namibia: time in which to solve their problems. . . .'I think history is against you,' I informed South African Ambassador Roelof "Pik" Botha ... "but we want to buy time at least ... If we can separate the South African issue from Rhodesia, it will give more time to deal with South Africaunless Rhodesia is settled in a way that accelerates the problem."78

Kissinger worried that if the front line states learned about these unprecedented South African agreements on Rhodesia and Namibia, they would simply pocket the concessions and go for more. So he would insist on secrecy about the results of his negotiations with Vorster during the next phase of the strategy. At the right time, he and his team planned to visit countries in the region dangling the prospect of South African flexibility - which he privately knew to be virtually assured -in order to firm up front line support for the American and British plan. "I do not tell anybody I have South African agreement on anything. [To the front line Presidents] I say: 'If I can get your support, I can try for this. If I get South African agreement, will you support it?"79

Provisional British and Front-line State Support Erodes. Britain's active support was essential to success. As the governing power displaced by Smith's unrecognized "declaration of independence," Kissinger's plan required Britain to return to Rhodesia temporarily while a new constitution was being drafted and then to preside over a legitimate transfer of power; the illegal Smith regime could not do this. Kissinger articulated the double negotiation challenge that this situation presented: "Britain would never agree to undertake the task unless requested to do so by the black frontline states, if then. It fell on us, therefore, to embark on the ironic dual mission of persuading reluctant Britain to reassume for a brief period the imperial mantle it had been shedding for three decades and to convince its former colonial subjects to invite their erstwhile rulers to return so that imperial rule could be abandoned properly and legitimately. ${ }^{80}$

Unfortunately for this "dual mission," the British appeared to be increasingly conflicted about a more affirmative role in the negotiations. British Prime Minister Callaghan and Foreign Secretary Crosland were nominally committed to Kissinger's diplomacy, but proved maddeningly vague on their support for specifics on vital issues. These included the white/black balance of senior roles during a Rhodesian transition, the extent of property and political protections as well as any compensation for white Rhodesians, and so on. The British had serious economic troubles at home, were concerned about military entanglement in Rhodesia, and had been double-crossed by Ian Smith too many times to be confident in mere assurances that the various parties were committed to a negotiation.

Provisional support by the front-line states was also becoming more tenuous by the day, with backsliding in all quarters. British hedging and the ongoing ambivalence of the frontline states mutually reinforced each other. Kissinger also suspected that Nyerere expected guerilla pressures on Rhodesia to 
mount, thus weakening its bargaining position if talks were delayed. Whatever the precise causes, with his strategy eroding in Africa and Britain as well as coming under intense domestic pressure from Republicans to desist, Kissinger ruminated that the "temptation to abandon the negotiation at this point was overwhelming." 81 Yet the tantalizing prospect of success seemed so close and the consequences of stopping seemed so awful that Kissinger decided to persist, but to completely rethink his strategy and tactics.

Dramatically Revising the Negotiating Strategy. In a nutshell, "the original strategy had been to work out a common position with the front-line states, take it to Vorster, and then impose it on Smith." 82 In light of British ambivalence driven in part by the increasing evasions of the front line state leaders, Kissinger dramatically altered his approach, upending the careful sequence by which his negotiations had originally proceeded. To build a supportive coalition, he now decided to "reverse the procedure.... [He] would try to work out a detailed proposal with Callaghan [in writing], obtain Vorster's support, clear the principles of it with the front-line Presidents, convince Smith with Vorster's help, and then bring it back to the front-line Presidents for their final approval." 83

This re-sequencing and tactical shift would require great finesse and a measure of luck. "It was a complicated scenario depending crucially on our stage-managing it in such a way as to have the final breakthrough emerge as Smith's acceptance of terms proposed by Britain and the United States to which the front-line states were invited to respond, and not as African concessions to Smith." 84 By this time, Kissinger knew that, if the proposal were seen to come from South Africa or Rhodesia, it would have no chance of regional acceptance.

Revised Strategy: The U.K., South Africa, and Front-line States. To pre-empt future British waffling or backsliding, Kissinger pressed for their proposal in writing. By the end of August, a joint UKUS working group produced the desired document. Prime Minister Callaghan and Foreign Secretary Crosland presented it to Kissinger in the Cabinet room in London. Now, Kissinger could use this text to firm up South African commitments, and nudge the hesitant Tanzanian president (Nyerere) back on board, gaining his agreement to convene the front-line leaders to persuade them to support a deal.

On Saturday, September 4, 1976, Kissinger met Vorster for the second time in two months, "in itself, a major event for the South Africans, for whom it spelled a symbolic end to their isolation." 85 The South Africans more firmly committed themselves to pressuring Rhodesia and became more specific and forthcoming on Namibia. Again, Kissinger planned to hold back this information in his next negotiations with the front-line states, as he explained to Ford: "I do not-repeat, not-plan to surface these papers with anyone at this stage, because it is essential that we not reveal South Africa's forthcoming position until the black Africans commit themselves more concretely." 86

Such selective revelation helped to advance the process, at least to the next stage. Deeply skeptical that Kissinger could secure such commitments from the South Africans or British, Julius Nyerere remarked "Supposing a miracle took place-I really think of is as a miracle-and Vorster gets Smith to say 'Majority rule must come; it's better that it come peacefully, so I accept Mr. Callaghan's position.' ... I'd be happy if ... the British call a constitutional conference." Of course Kissinger "knew from [Foreign Secretary] Crosland that Britain would agree to call such a conference. And I knew from Vorster - though Nyerere did not - that the 'miracle' of Smith's acceptance of majority rule was awaiting me in [South Africa's capitol] Pretoria." 87 Nyerere went on, "in effect, endorsed our diplomacy." 88 Generally successful meetings with other African leaders followed.

Revised Strategy: Getting Ian Smith to Say "Yes" and Dealing with an Unwelcome London Surprise. When South Africa publicly committed to greater flexibility on Namibian independence and British support shored up, Kissinger and his team made a second African trip. They arranged to meet Vorster again, this time in Pretoria - but only if Vorster could deliver an Ian Smith who would be open to majority black rule in Rhodesia within two years. This would be a tough sell. Even with a worsening 
military outlook and collapsing regional trade, Ian Smith had remained defiant, convinced that the United States and South Africa would be forced to come to his aid or the entire region would be ceded to the Cubans and Soviets. ${ }^{89}$ Unflinching, he had refused to accommodate any South African requests that he moderate his course. In a virtual rebuke to Vorster and shock to the international community in early August, Smith's troops carried out a raid into neighboring Mozambique where they massacred some 1,000 men, women, and children in a guerilla camp. ${ }^{90}$

Vorster Delivers an Ultimatum. Exasperated with Smith, the South Africans pulled their longstanding military helicopter crews and signalers from Rhodesia at the end of August. ${ }^{91}$ Vorster sent a message - he was finished dealing with Smith's hardline Defense Minister and wished to hold conversations with the more moderate ... Minister of Finance. ${ }^{92}$ Following Mozambique's closure of the border in March, Rhodesia had become increasingly reliant on South Africa for access to the outside world. Most essential imports and exports that sustained Rhodesia's economy and Smith's war effortincluding produce, oil, weapons, and minerals - now had to travel through South Africa. ${ }^{93}$ So when, prior to his meeting with Kissinger, Vorster delivered an ultimatum to Smith to accept the principles in the Anglo-American memorandum "or else," the Rhodesian leader was cornered.

Meeting with Ian Smith. Ian Smith contemplated his upcoming negotiations with Henry Kissinger with a sense of foreboding, if not dread, having just experienced another dose of "Vorster's arm-twisting" as well as the South African's explanation of "the kind of plan Kissinger would bring."94

As Kissinger planned to meet with Ian Smith and his Rhodesian colleagues in Pretoria on September 19, 1976, the American remarked that "Even though it had been my diplomacy which had closed off Smith's every escape route, I nevertheless did not relish having to tell my interlocutors that their way of life was coming to an end." 95 A lengthy, though respectful, negotiation ensued with Kissinger finally bringing matters to a head after offering - in line with the U.S.-British document that had been shown to Vorster - to support provisions to protect white minority property and political rights as well as discussing the prospects for compensation for those forced off their land. In return, Kissinger's conditions crystallized: Smith would have to take part in all-party negotiations, publicly accepting the talks with the precondition that majority black rule would prevail in Rhodesia within two years.

The Rhodesian Prime Minister later reflected at length about the somber, even empathetic, approach Kissinger took during these daylong negotiations, which in effect, delivered a brutal ultimatum to the white regime. In Smith's words, "Kissinger admitted that the package he had to offer was unattractive, but it was the best he could extract from the other parties, the British government and the front-line states, who had to be taken along. . . . [The U.S.] Congress had refused to support him and President Ford whenever they tried to take a strong line, e.g. in Angola, when even the loud-talking conservatives had collapsed and voted with the 'Nos'. He did not see the free world lifting a finger to help us, and, with the passage of time, he only saw our position deteriorating. On the evidence now available it looked as if Gerald Ford would lose the presidential election at the end of the year, and with Carter in office then the Lord help us ... Once again, he stressed that his heart was heavy for us ... If we rejected this offer, there would be understanding and sympathy, never recrimination from him. . . The decision was for us to make." 96

Smith recalled that "[Kissinger] spoke with obvious sincerity, and there was great emotion in his voice. For awhile, words escaped him ... If we agreed that day, he would fly off immediately to reconfirm the plan with Kaunda and Nyerere. If we rejected it, he would be off to the other side of the world for his business there, and Rhodesia would be behind him. ... All of us were impressed by Kissinger's sincerity and straightforward approach . . ."97 Ken Flower, longtime Chief of Rhodesia's Intelligence Service and a participant in these talks, wrote in his diary "Most impressed with K's grasp of the situation. He was well ahead of his staff in providing answers on debating points as they cropped up. 
.. As we broke for lunch Kissinger kept saying how much he appreciated Rhodesia's position: how he would not know what decision to make if he were in Ian Smith's shoes."98

However softly the message was delivered, Smith bitterly reflected on the deciding factor (engineered, of course, by Kissinger's earlier negotiations): "South African eagerness to throw us to the wolves in their desperate panic to try to buy time and gain credit for solving the Rhodesian problem." 99 "[W] e were confronted by the one country in the world [South Africa] that controlled our lifeline, and which had now issued an ultimatum leaving us no alternative." 100 Cornered, the Rhodesian Prime Minister agreed to the framework.

Reflecting on the negotiations, Smith ruefully stated that Kissinger "made unequivocally clear that this was a package deal tied up by the British, Americans and South Africans on the one side and the black presidents (Kaunda and Nyerere) on the other, and that there could be no going back over all that ground again. Our option was to accept or reject. If we rejected, the next offer would only be worse . . ."101 As Smith later declared, "it was made abundantly clear to me ... [that] we could expect no ... support of any kind from the free world. On the contrary, the pressures on us from the free world would continue to mount. Dr. Kissinger has been working in close consultation with the British government, and he has the full support of the other major Western powers."102

While Smith returned to Rhodesia, Kissinger met once again with Nyerere and Kaunda, carrying news of Smith's agreement as well as Vorster's commitment to move forward on Namibia. ${ }^{103}$ In Lusaka and Dar es Salaam, the presidents congratulated him on the deal, indicated their support privately, but held back on ringing public endorsements. Although Kissinger was sure that they would join all-party talks, he understood that both had hardline constituents and allies. They would need to proceed cautiously.

As Kissinger travelled, it became clear that Nyerere and Kaunda viewed the "details" of the British-American framework as something to be worked out through negotiation by all parties. In contrast, ahead of any negotiations, Smith worked on Kissinger's associates to tie down - favorably to Rhodesia - "details" beyond the written framework itself including, for example, institutional protection for whites during a transition, a possible compensation fund for white Rhodesians and the racial composition of the two-year transition regime. Resisting, the American team would not go beyond Kissinger's verbal commitments to explore various aspects of the agreement on the Rhodesians' behalf. Precisely what had been agreed and by whom would prove controversial in the coming negotiations.

Five days after his talks with Kissinger, on Friday September 24, Smith made a televised announcement, publicly confirming his acceptance of the principle of majority rule within two years, and agreement to participate in the negotiations. ${ }^{104} \mathrm{He}$ characterized this statement as a "savage blow." $105 \mathrm{On}$ the plane at the time, the American team cheered at the news. ${ }^{106}$ Close observers record the "stunning effect of Smith's broadcast on the Rhodesian white population." 107 For Smith's Intelligence Chief, Ken Flower, the announcement, "turned the world upside down for most Rhodesians;" 108 in the words of Bishop Abel Muzorewa, Smith's broadcast "electrified the world."109

Barely six months before, Smith had defiantly declared that black majority rule would not come for "a thousand years." Kissinger's Assistant Secretary of State William Schaufele commented that with their one meeting in Pretoria on September 19, "we reduced this period... by 98.9 percent."110

In a "fighting statement," the front-line presidents publicly hailed Smith's statement as the "collapse" of the illegal, racist Rhodesian regime, framing it as a victory for the guerilla freedom fighters without mentioning U.S.-British diplomacy. Privately, however, they accepted the framework and plan for negotiations. True to the form that Kissinger had often observed, Nyerere explained "You and I, Dr. Kissinger, have very different 'political constituencies' to take account of, and inevitably, there is a danger 
that in dealing with them we shall each appear insensitive to the problems of the other ... I hope that through frank and friendly contact we can reduce misunderstandings between us to the minimum."111

A "Spectacular Climax." Globally, this shocking and unexpected turnabout by the Rhodesian government drew banner headlines heralding "Kissinger's amazing diplomatic triumph... Television and newspaper photos showed him announcing the agreement while holding a ceremonial tribal sword and shield presented to him by President Jomo Kenyatta in Kenya ... [Kissinger] . . .was featured on the covers of the newsmagazines, and Time proclaimed it the spectacular climax of a carefully and astutely planned push for peace."'112

The Geneva Conference and Beyond. Intended as the capstone of Kissinger's negotiation campaign to achieve majority rule in Rhodesia, the Geneva conference soon fizzled. While a complex of factors delayed the result for three years, many well-placed observers would credit Smith's announcement as a turning point in the region's long path to shaking off white minority rule.

The path proved to be bumpy and indirect. On November 2, 1976, scarcely after the British had convened the negotiations without the participation of their Foreign Secretary, Jimmy Carter beat Gerald Ford in the U.S. presidential election. Though Ford had defeated Ronald Reagan's Republican primary challenge, Ford's election loss transformed Kissinger into a lame duck Secretary, unable to hold the process together. With Kissinger on the way out, British confidence in and commitment to the Geneva process sharply declined. Carter would soon take office with an uncompromising anti-apartheid stance that quickly eroded Vorster's incentives to keep up the pressure on Rhodesia. ${ }^{113}$

Over the next few years, guerilla violence sharply increased as Smith unsuccessfully sought to negotiate with Rhodesia's black leaders. When Conservative Margaret Thatcher became British Prime Minister, she convened negotiations in London's Lancaster House. The white Rhodesians felt more comfortable with Thatcher than they had been with previous Labor governments. Even so, the negotiations largely followed the Kissinger script, concluding in December 1979 with a new constitution for Zimbabwe ensuring black majority rule.

Majority rule in Zimbabwe was a victory for democratic political principle, but in practice would usher in what ultimately became a disastrous regime. In 1980, Robert Mugabe won a landslide election to become the first black Prime Minister of a newly independent Zimbabwe. ${ }^{114}$ Ian Smith remained on his farm even as 100,000 whites fled, until ailing health took him to Cape Town, where he died in 2007.115 Repression, violence, and economic failure increasingly characterized Mugabe's tenure as he ruthlessly consolidated power over the government and military. ${ }^{116}$ In global rankings of GDP per capita, World Bank and IMF estimates placed Zimbabwe at the $45^{\text {th }}$ percentile in 1976 when Smith made his announcement; by 2016, its economy had plummeted to the bottom $15 \% .117$ Its economy in tatters, corruption rife, much of its population destitute, Zimbabwe had once again become a pariah state, this time under the near-dictatorial rule of the 91 year-old Mugabe, having displaced the white regime headed by Ian Smith some 40 years before. ${ }^{118}$

As Kissinger had expected, the demise of minority rule in Rhodesia bought time for South Africa but not stability. John Vorster was succeeded by the harder-line P.W. Botha, who presided over increasing civil unrest, violence, and boycotts until his rival, F.W. de Klerk, took power. ${ }^{119}$ With the writing on the wall, de Klerk negotiated majority rule with Nelson Mandela, who was dramatically elected South Africa's first black president in 1994, ending nearly half a century of apartheid, with happier results than in Zimbabwe. ${ }^{120}$ Like South Africa, Namibia struggled amidst worsening violence toward majority rule until 1990, when SWAPO leader Sam Nujoma was elected the country's first president. ${ }^{121}$

Evaluating the Results of Kissinger's Negotiations. Twenty years after the fact, Stephen Low, then American Ambassador to Zambia, observed that "Kissinger had completely changed U.S. policy, 
taken over the negotiations between the independent but illegal white Southern Rhodesian government and the Africans, introduced the principle of majority rule as the basis for world recognition of the independence of Southern Rhodesia and gotten it accepted by the Smith white ruled government of the country." 122 Winston Lord, Director of Policy Planning at State and later U.S. Ambassador China, concluded in 1998 that "Rhodesia became independent eventually as a result of Kissinger diplomacy ... [This was] one of Kissinger's major diplomatic achievements, and least heralded."123

Frank G. Wisner - whose later diplomatic career included ambassadorships to India, the Philippines, and Egypt - fleshed out the conclusions articulated by Low, Lord, and Davidow:

Kissinger's plan was to create a set of propositions around which a transition to elections and a transition to majority rule would take place, over a period of time: a set of propositions that he would sell first to the Africans, then having already started working on John Vorster, finish the job with the South Africans and then get them to help him sell it to the Rhodesians, then get the two parties together -- the white minority regime and the cantankerous and divided nationalist side together in a final conference and put it back under British authority and then have Britain hold the brass ring. Kissinger's conception was brilliant, and his execution was admirable. That he failed to reach $100 \%$-is not to gainsay the fact that he got us well along that path and opened the door for what ended up later, an independent Zimbabwe ... [These efforts helped] set the stage for Maggie Thatcher to come on board and to kick-start Lancaster House, get an agreement and bring Rhodesia to independence. ${ }^{124}$

In this spirit, Walter Isaacson's often sharply critical biography of Kissinger observed that "the outlines of the Kissinger agreement would serve as the basis" for the Lancaster House negotiations that completed the process. And Isaacson concluded, "Even though Kissinger's shuttle did not immediately produce the solution that was celebrated in September, it succeeded in its larger aims. The nations of black Africa, whose attitude toward the U.S. had ranged from wariness to hostility, began to trust Washington as a force for majority rule. The growing appeal of the Soviet Union was countered."125

Some twenty-three years after these events, Kissinger rendered his own verdict: "From the geopolitical perspective, we had achieved the purpose of our African diplomacy. Six months after the debacle of Angola, the United States was demonstrating a continuing capacity to shape events in Africa . . . Rhodesia and Namibia became independent, implementing principles and procedures agreed during the African shuttles - though more slowly and with the emergence of more radical governments, especially in Rhodesia, than we would have liked. International war in Southern Africa was avoided ... there were to be no other Cuban adventures in the independence struggles of Southern Africa."126

\section{References}

Bauer, Gretchen. "Namibia in the First Decade of Independence: How Democratic?". Journal of Southern African Studies 27, no. 1 (2001): 33-55.

"Biographies of the Secretaries of State: Henry A. (Heinz Alfred) Kissinger (1923-)." edited by U.S. Department of State: Office of the Historian.

"Biography of Henry A. Kissinger." http://henryakissinger.com/ 
files/290/henryakissinger.com.html.

Callaghan, James. "Address to the Labour Party Conference at Blackpool." 1976.

Compagnon, Daniel. A Predictable Tragedy : Robert Mugabe and the Collapse of Zimbabwe. Philadelphia: University of Pennsylvania Press, 2011.

Cowell, Alan. "Ian Smith, Defiant and Steadfast Symbol of White Rule in Africa, Is Dead at 88." New York Times, Nov. 21, 2007, A25.

Dombroski, Kenneth R. "South Africa after Apartheid." Journal of Democracy 17, no. 3 (2006): 43-57.

Easum, Donald B. "Nyerere and Obasanjo on Rhodesia, Report to Secretary of State Henry A. Kissinger, November 23, 1976." edited by U.S. Department of State: Department of State, 1976.

Flower, Ken. Serving Secretly: An Intelligence Chief on Record : Rhodesia into Zimbabwe, 1964 to 1981. London: J. Murray, 1987.

Ford, Gerald R. A Time to Heal : The Autobiography of Gerald R. Ford. New York: Harper \& Row, 1979.

Gleijeses, Piero. "A Test of Wills: Jimmy Carter, South Africa, and the Independence of Namibia." Diplomatic History 34, no. 5 (2010): 853-91.

"Henry Kissinger - Biographical." http://www.nobelprize.org/nobel_prizes/peace/laureates/1973/kissinger-bio.html.

Howe, Herbert. Dancing on Cobwebs: American Diplomatic Participation in the 1976 Rhodesian Peace Process. Pew Case Studies in International Affairs. Washington, D.C., United States: Pew Charitable Trusts, 1988.

Isaacson, Walter. Kissinger : A Biography. New York: Simon \& Schuster, 1992.

Jackson, Paul. "The Civil War Roots of Military Domination in Zimbabwe: The Integration Process Following the Rhodesian War and the Road to Zanla Dominance." Civil Wars 13, no. 4 (2011): 37195.

Kalb, Marvin. First Line Report, CBS Radio, Morning, May 4, 1976.

Kamm, Henry. "Rhodesian Drama Engrosses South Africa." New York Times, Mar. 22, 1976, 3.

Kaufman, Michael T. "Chrome Ban Asked: secretary, in Zambia, States Africa Policy and Promises Aid Kissinger to Press Rhodesia on Rule by Black Majority." New York Times, Apr. 28, 1976, 85.

Kissinger, Henry. "Comments on Draft National Intelligence Estimate on Rhodesia." edited by Department of State, 1976.

- - - Years of Renewal. New York: Simon \& Schuster, 1999.

Kissinger, Henry A. "Document 195 - Southern Africa - Historical Documents - April 27, 1976." edited by U.S. Department of State: Office of the Historian, 1976.

Knowles, Elizabeth. Oxford Dictionary of Modern Quotations. 3 ed. 2008.

Lake, Anthony. The "Tar Baby" Option: American Policy toward Southern Rhodesia. New York: Columbia University Press, 1976.

Lax, David A., and James K. Sebenius. "Deal Making 2.0: A Guide to Complex Negotiations." Harvard Business Review 90, no. 12 (November 2012): 92-100.

"List of Countries by Past and Projected Gdp (Nominal) Per Capita." Wikipedia, https://en.wikipedia.org/w/index.php?title=List_of_Countries_by_past_and_projected_GDP_( nominal)_per_capita\&oldid=711796013.

Lord, Winston. "Interview with Ambassador Winston Lord." By Charles Stuart Kennedy and Nancy Bernkopf Tucker. Foreign Affairs Oral History Project (Apr. 28 1998).

Low, Stephen. "Interview with Stephen Low." Foreign Affairs Oral History Project (1988).

Martin, David. "Mwalimu Julius Kambarage Nyerere Remembered." Southern Africa Research and Documentation Centre.

McNeil, Jr Donald G. "Joshua Nkomo of Zimbabwe Is Dead at 62." New York Times, July 2, 1999, C17.

Muzorewa, Abel Tendekayi. Rise up and Walk : An Autobiography. Edited by Norman E. Thomas London: Evans Books, 1978.

Onslow, Sue. "'Noises Off': South Africa and the Lancaster House Settlement 1979-1980." Journal of Southern African Studies 35, no. 2 (2009): 489-506.

- - - . "A Question of Timing: South Africa and Rhodesia's Unilateral Declaration of Independence, 1964-65." Cold War History 5, no. 2 (2005): 129-59. 
- - - . "South Africa and the Owen/Vance Plan of 1977." South African Historical Journal 51, no. 1 (2004): 130-58.

- - - "'We Must Gain Time': South Africa, Rhodesia and the Kissinger Initiative of 1976." South African Historical Journal 56, no. 1 (2006): 123-53.

"Poised between Peace and War." Time, Oct. 11, 1976, 44.

Resolution 385 Adopted by the United Nations Security Council at Its 1885th Meeting. S/RES/385. 1885, Jan. 30, 1976.

"The Road to Zimbabwe." The Observer, Sep. 26, 1976, 8.

Rotberg, Robert. "Namibia's Nationhood." The Christian Science Monitor, Mar. 20, 1990, 19.

Schaufele, Jr William E. "Interview with Ambassador William E. Schaufele, Jr." Foreign Affairs Oral History Project (Nov. 19, 1994).

Sebenius, James K. "Level Two Negotiations: Helping the Other Side Meet Its "Behind-the-Table" Challenges." Negotiation Journal 29, no. 1 (2013): 7-21.

"Secretary's Visit to Tanzania - March 25, 1976." edited by U.S. Department of State, 1976.

Smith, Ian Douglas. Bitter Harvest. London: Blake, 2001.

- - - . The Great Betrayal: The Memoirs of Ian Douglas Smith. London: Blake Publishing Ltd, 1997.

"Smith Speech - September 21, 1976." edited by U.S. Department of State, 1976.

Smock, David R. "The Forgotten Rhodesians." Foreign Affairs; an American Quarterly Review 47, no. 3 (1969): 532.

"Twilight in Pretoria." New York Times, Feb. 5, 1989, E24.

Van Der Vat, Dan. "Ian Smith, 88 Politician." The Globe and Mail, Nov. 21, 2007, S10.

Walton, Hanes. The African Foreign Policy of Secretary of State Henry Kissinger : A Documentary Analysis [in eng]. Lanham: Lexington Books, 2007.

White, Luise. Unpopular Sovereignty : Rhodesian Independence and African Decolonization. Chicago: The University of Chicago Press, 2015.

"Whites in Africa Fear Race War." Morning Journal-Record, Feb. 28, 1976, 7.

Wisner, Frank G. "Interview with Ambassador Frank G. Wisner." By R. Nicholas Burns, Laurence A. Green, Eugene Kogan, Robert Mnookin and James K. Sebenius (May 5, 2016).

Wright, Robin. "Vorster and Smith Hold Talks on Kissinger's Africa Shuttle." The Washington Post, Sept. 15, 1976, A10.

"Zimbabwe: Mugabe Booed over Economic Crisis." Africa Research Bulletin: Economic, Financial and Technical Series 52, no. 8 (2015).

"Zimbabwe's Landslide Leader." The Christian Science Monitor, Mar. 5, 1980, 24.

${ }^{1}$ Henry Kissinger, Years of Renewal (New York: Simon \& Schuster, 1999), 903.

${ }^{2}$ Elizabeth Knowles, Oxford Dictionary of Modern Quotations, 3 ed. (2008), 296.

${ }^{3}$ Kissinger, 1011.

${ }^{4}$ The quoted phrase is from ibid., 961.

5 "Poised between Peace and War," Time, Oct. 11, 1976.

6 "The Road to Zimbabwe," The Observer, Sep. 26, 1976.

${ }^{7}$ Kissinger, 972.

8 "Biographies of the Secretaries of State: Henry A. (Heinz Alfred) Kissinger (1923-)," ed. U.S. Department of State (Office of the Historian).

9 "Biography of Henry A. Kissinger," http:/ / henryakissinger.com/

files/290/henryakissinger.com.html.

${ }^{10}$ Walter Isaacson, Kissinger : A Biography (New York: Simon \& Schuster, 1992).

11 "Biography of Henry A. Kissinger".

12 "Biographies of the Secretaries of State: Henry A. (Heinz Alfred) Kissinger (1923-)."

13 "Henry Kissinger - Biographical," http://www.nobelprize.org/nobel_prizes/peace/laureates/1973/kissinger-bio.html.

14 "Whites in Africa Fear Race War," Morning Journal-Record, Feb. 28, 1976.

${ }^{15}$ Kissinger, 917-18.

16 Anthony Lake, The "Tar Baby" Option : American Policy toward Southern Rhodesia (New York: Columbia University Press, 1976).

17 Isaacson, 822. 
${ }^{18}$ Kissinger, 925.

${ }^{19}$ See, for example, David R. Smock, "The Forgotten Rhodesians," Foreign Affairs; an American Quarterly Review 47, no. 3 (1969); Sue Onslow, "A Question of Timing: South Africa and Rhodesia's Unilateral Declaration of Independence, 1964-65," Cold War History 5, no. 2 (2005); Luise White, Unpopular Sovereignty : Rhodesian Independence and African Decolonization (Chicago: The University of Chicago Press, 2015).

${ }^{20}$ Alan Cowell, "Ian Smith, Defiant and Steadfast Symbol of White Rule in Africa, Is Dead at 88," New York Times, Nov. $21,2007$.

21 Kissinger, 975.

${ }^{22}$ Hanes Walton, The African Foreign Policy of Secretary of State Henry Kissinger : A Documentary Analysis (Lanham: Lexington Books, 2007), 208.

23 Kissinger, 918.

24 Ibid., 916-17.

25 Ibid., 917.

${ }^{26}$ Gerald R. Ford, A Time to Heal : The Autobiography of Gerald R. Ford (New York: Harper \& Row, 1979$), 380$.

27 Kissinger, 918.

${ }^{28}$ This simplified diagram leaves out many figures that, in a fuller account of these negotiations, would be seen to have roles. Such figures would include, for example, Abel Muzorewa, Robert Mugabe, Jomo Kenyatta, as well as the heads of a number of African states and their foreign ministers. For a fuller exposition in business contexts, see David A. Lax and James K. Sebenius, "Deal Making 2.0: A Guide to Complex Negotiations," Harvard Business Review 90, no. 12 (November 2012): $92-100$.

29 Ibid.

${ }^{30}$ Kissinger, 918.; ibid., 918-19.

31 Ibid., 921.

32 For example, "Comments on Draft National Intelligence Estimate on Rhodesia," ed. Department of State (1976); Donald B. Easum, "Nyerere and Obasanjo on Rhodesia, Report to Secretary of State Henry A. Kissinger, November 23, 1976," ed. U.S. Department of State (Department of State, 1976); "Secretary's Visit to Tanzania - March 25, 1976," ed. U.S. Department of State (1976); "Smith Speech - September 21, 1976," ed. U.S. Department of State (1976).

${ }^{33}$ Kissinger, Years of Renewal, 914.

${ }^{34}$ Ford, 380.

35 James Callaghan, "Address to the Labour Party Conference at Blackpool," (1976).

36 Kissinger, Years of Renewal, 925.

37 Ibid., 916, 25.

38 Ibid., 932-33.

39 Ibid., 932.

${ }^{40}$ David Martin, "Mwalimu Julius Kambarage Nyerere Remembered," Southern Africa Research and Documentation Centre.

${ }^{41}$ Herbert Howe, Dancing on Cobwebs: American Diplomatic Participation in the 1976 Rhodesian Peace Process, Pew Case Studies in International Affairs (Washington, D.C., United States: Pew Charitable Trusts, 1988), 6.

${ }^{42}$ Kissinger, Years of Renewal, 931.

43 Ibid., 936.

${ }^{44}$ Henry A. Kissinger, "Document 195 - Southern Africa - Historical Documents - April 27, 1976," ed. U.S. Department of State,

Foreign Relations of the United States, 1969-1976 (Office of the Historian, 1976); Michael T. Kaufman, "Chrome Ban

Asked: secretary, in Zambia, States Africa Policy and Promises Aid Kissinger to Press Rhodesia on Rule by Black Majority," New York Times, Apr. 28, 1976.

${ }^{45}$ For example, Kissinger forged a relationship with the President of the Ivory Coast, Félix Houphouët-Boigny, a former French senator who would act as a sounding board throughout the negotiations. Kissinger.; Kissinger, Years of Renewal, 939.

${ }^{46}$ Kaufman.

${ }^{47}$ Kissinger, Years of Renewal, 942.

48 Ibid., 943.

49 Ibid., 950

50 Ibid., 953-54.

${ }^{51} \mathrm{Ibid}$. Consistent with their support, the ministers agreed to provide only one channel for supplying weapons to the Rhodesian opposition, thereby limiting the ability of the Cubans to traffic arms through the region.

52 Marvin Kalb, First Line Report, CBS Radio, Morning, May 4, 1976.

${ }^{53}$ Kissinger, Years of Renewal, 940.

${ }^{54}$ Kissinger, Henry (2011-06-21). Years of Renewal (Kindle Locations 16268-16269). Simon \& Schuster. Kindle Edition.

55 Ibid, Kindle locations 16628-16275.

${ }^{56}$ Kissinger, Years of Renewal, 983.

57 Walton, 71, 73.

${ }^{58}$ Kissinger, Years of Renewal, 921-22; Walton, 73.

${ }^{59}$ Kissinger, Years of Renewal, 921-22.For example, beyond the Rev. Jesse Jackson, Kissinger met with Dr. Leon Sullivan, who had worked extensively with U.S. companies about their policies in South Africa, Transportation Secretary William T. Coleman, etc. ; Walton, 73.

${ }^{60}$ Kissinger, Years of Renewal, 956.

${ }^{61}$ Ibid., 961.

62 ibid.

${ }^{63}$ Resolution 385 Adopted by the United Nations Security Council at Its 1885th Meeting, S/RES/385, 1885 (Jan. 30, 1976). 
${ }^{64}$ Sue Onslow, "“We Must Gain Time': South Africa, Rhodesia and the Kissinger Initiative of 1976," South African Historical Journal 56, no. 1 (2006): 131.

65 ibid., 129-30, 40-41.

66 Ibid., 140.

${ }^{67}$ Ibid., 129-30.

${ }_{68}^{6}$ Kissinger, Years of Renewal, 958.

${ }^{69}$ Ibid., 964.

70 Ibid.

${ }^{71}$ Ibid., 966; Sue Onslow, "'Noises Off': South Africa and the Lancaster House Settlement 1979-1980," Journal of Southern African Studies 35, no. 2 (2009): 490.

72 Kissinger, Years of Renewal, 969.

${ }^{73}$ Kissinger, Years of Renewal, 968.

${ }^{74}$ Ibid.

75 Ibid.

${ }^{76}$ Ibid., 969.

77 Ibid.

78 Ibid., 959.

${ }^{79}$ Ibid., 975.

${ }^{80}$ Ibid., 973.

${ }^{81}$ Ibid., 979.

82 Ibid., 980.

${ }^{83}$ Ibid.

${ }^{84}$ Ibid.

${ }^{85}$ Ibid., 985.

${ }^{86}$ Ibid., 986-87.

87 Ibid., 991.

${ }^{88}$ Ibid., 992.

${ }^{89}$ Onslow, "‘We Must Gain Time': South Africa, Rhodesia and the Kissinger Initiative of 1976," 146.

90 Ibid., 142.

${ }^{91}$ Ibid., 143.

92 Ibid., 128; Ian Douglas Smith, The Great Betrayal: The Memoirs of Ian Douglas Smith (London: Blake Publishing Ltd, 1997$), 196$.

${ }_{93}$ Onslow, "'We Must Gain Time': South Africa, Rhodesia and the Kissinger Initiative of 1976," 144; Henry Kamm, "Rhodesian

Drama Engrosses South Africa," New York Times, Mar. 22, 1976; Robin Wright, "Vorster and Smith Hold Talks on Kissinger's Africa Shuttle," The Washington Post, Sept. 15, 1976.

${ }_{94}$ Smith, 198-99.

${ }^{95}$ Kissinger, Years of Renewal, 998.

${ }_{96}$ Smith, 201-2.

${ }^{97}$ Ibid., 203, 07.

${ }^{98}$ Ken Flower, Serving Secretly : An Intelligence Chief on Record : Rhodesia into Zimbabwe, 1964 to 1981 (London: J. Murray, 1987$), 170$.

99 Smith, 207.

100 Ibid., 209.

101 Bitter Harvest (London: Blake, 2001), 202-3.

102 Kissinger, Years of Renewal, 1011-12.

103 Ibid., 985-87.

104 Ibid., 1011.

${ }^{105}$ Smith, The Great Betrayal: The Memoirs of Ian Douglas Smith, 210.

${ }^{106}$ Frank G. Wisner, interview by R. Nicholas Burns, et al., May 5, 2016.

${ }^{107}$ For an elaboration, see Onslow, "“We Must Gain Time': South Africa, Rhodesia and the Kissinger Initiative of 1976," 123. Also see, Flower, 152.

${ }_{108}$ Abel Tendekayi Muzorewa, Rise up and Walk: An Autobiography, ed. Norman E. Thomas (London: Evans Books, 1978 ), 208.

109 Jr William E. Schaufele, Nov. 19, 1994.

${ }^{110}$ Kissinger, Years of Renewal, 1013-14.

111 James K. Sebenius, "Level Two Negotiations: Helping the Other Side Meet Its "Behind-the-Table" Challenges," Negotiation Journal 29, no. 1 (2013).

112 Isaacson, 691.

${ }^{113}$ Piero Gleijeses, "A Test of Wills: Jimmy Carter, South Africa, and the Independence of Namibia," Diplomatic History 34, no. 5 (2010); Sue Onslow, "South Africa and the Owen/Vance Plan of 1977," South African Historical Journal 51, no. 1 (2004).

114 "Zimbabwe's Landslide Leader," The Christian Science Monitor, Mar. 5, 1980.

${ }^{115}$ Dan Van Der Vat, "Ian Smith, 88 Politician," The Globe and Mail, Nov. 21, 2007.

116 Jr Donald G. McNeil, "Joshua Nkomo of Zimbabwe Is Dead at 62," New York Times, July 2, 1999; Paul Jackson, "The Civil War Roots of Military Domination in Zimbabwe: The Integration Process Following the Rhodesian War and the Road to Zanla Dominance," Civil Wars 13, no. 4 (2011): 385-89.

117 "List of Countries by Past and Projected Gdp (Nominal) Per Capita," Wikipedia,

https://en.wikipedia.org/w/index.php?title=List_of_Countries_by_past_and_projected_GDP_(nominal)_per_capita\&oldid=71179 6013. 
118 Daniel Compagnon, A Predictable Tragedy : Robert Mugabe and the Collapse of Zimbabwe (Philadelphia: University of Pennsylvania Press, 2011), 254-60; "Zimbabwe: Mugabe Booed over Economic Crisis," Africa Research Bulletin: Economic, Financial and Technical Series 52, no. 8 (2015).

119 "Twilight in Pretoria," New York Times, Feb. 5, 1989.

${ }^{120}$ Kenneth R. Dombroski, "South Africa after Apartheid," Journal of Democracy 17, no. 3 (2006): 43-57.

${ }^{121}$ Gretchen Bauer, "Namibia in the First Decade of Independence: How Democratic?," Journal of Southern African Studies 27, no. 1

(2001): 33-55; Robert Rotberg, "Namibia's Nationhood," The Christian Science Monitor, Mar. 20, 1990.

122 Stephen Low, 1988.

${ }^{123}$ Winston Lord, interview by Charles Stuart Kennedy and Nancy Bernkopf Tucker, Apr. 28, 1998.

124 Wisner.

125 Isaacson, 691-2.

126 Kissinger, Years of Renewal, 1015. 